\title{
Tapak Suci dan Karakter Siswa
}

\author{
Sukarni \\ Andi Sukri Syamsuri \\ Universitas Muhammadiyah Makassar \\ andissukrisyamsuri@unismuh.ac.id \\ Muhammad Nawir \\ Universitas Muhammadiyah Makassar \\ muhammadnawir@unismuh.ac.id
}

\begin{abstract}
ABSTRAK
Penelitian ini bertujuan untuk mengetahui bagaimana peranan tapak suci dalam membentuk karakter siswa di SMA Negeri 1 Malangke Kabupaten Luwu Utara. Jenis penelitian yang digunakan dalam penelitian ini adalah jenis penelitian bersifat kualitatif dengan bentuk deskriptif. Teknik pengumpulan data dalam penelitian ini menggunakan metode observasi, wawancara, dan dokumentasi. Subjek penelitian ini adalah siswa, dengan kriteria siswa yang ikut dalam ekstrakurikuler Tapak suci. Data dari hasil wawancara diorganisasikan, dikelompokkan, dan selama atau sesudah analisis data dilakukan telaah kepustakaan yang relevan dengan masalah penelitian ini. Kegiatan analisis data ialah mengatur, mengukur, mengelompokkan, memberikan kode, dan mengategorikannya. Proses pembentukkan karakter siswa dalam kegiatan ekstrakurikuler tapak suci di SMA Negeri 1 Malangke dilaksanakan seperti menanamkan nilai disiplin, seperti datang tepat waktu, menaati peraturan, dan disiplin beribadah. Nilai religius ditanamkan melalui berdoa sebelum dan sesudah latihan, wisata alam, melaksanakan shalat. Nilai kreatif ditanamkan melalui penguasaan jurus tapak suci dan melalui kegiatan seperti bakti sosial yang memancing daya pikir siswa. Nilai komunikatif ditanamkan melalui kegiatan dan penugasan kelompok serta siswa yang dekat dengan pelatih untuk bercerita masalahnya. Nilai menghargai prestasi ditanamkan melalui pemberiaan penghargaan bagi siswa yang menang pertandingan dan menerima kekalahan jika belum berhasil menang. Nilai cinta tanah air ditanamkan menggunaan seragam tapak suci dan bahasa resmi ketika latihan serta melalui pengajaran materi ke-tapak suci-an. Nilai peduli sosial ditanamkan melalui kegiatan yang berguna bagi kepentingan bersama seperti bakti sosial.
\end{abstract}

Kata Kunci : Tapak Suci,Karakter, Siswa

\section{PENDAHULUAN}

Muhammadiyah merupakan salah satu gerakan Islam, dakwah amar ma'ruf nahi mungkar, berakidah Islam dan bersumber dari Qu'ran dan sunnah yang didirikan oleh KH. Ahmad Dahlan pada tanggal 8 Dzulhidjah 1330 hijiriyah bertepatan pada tanggal 18 November 1912 miladiyah. Muhammadiyah banyak mengadakan gerakan-gerakannya melalui dunia pendidikan. Dunia pendidikan Muhammadiyah mengalami kemajuan yang sangat pesat sejak berdirinya hingga saat ini. Pesatnya pendidikan Muhammadiyah dapat kita lihat dalam lembaga-lembaga di bawah badan amal-usaha Muhammadiyah yang bergerak dalam bidang pendidikan. Hal ini membuktikan bahwasanya gerakan perubahan 
yang dibawa oleh Muhammadiyah dengan pendidikannya menjadi sesuatu yang cukup penting dalam kehidupan berbangsa dan bernegara. Dalam setiap pendidikan tentu memiliki suatu tujuan yang ingin dicapai, dan adapun tujuan pendidikan nasional yaitu untuk mengembangkan potensi siswa agar menjadi manusia yang beriman dan bertakwa kepada Tuhan Yang Maha Esa dan berbudi pekerti luhur, memiliki pengetahuan dan keterampilan, kesehatan jasmani dan rohani, kepribadian yang mantap dan mandiri serta rasa tanggung jawab kemasyarakatan dan kebangsaan.

Sebagai putera Indonesia, organisasi beladiri tapak suci putera Muhammadiyah mengabdikan diri, berperan serta mendidik dan membina manusia agar menjadi manusia beriman dan berakhlak, terampil, serta sehat jasmani dan rohani. Karena dengan imam dan akhlak akan menjadi kuat, tanpa iman dan akhlak akan menjadi lemah. Untuk membentuk sikap mental dalam diri setiap individu dan ataupun kolektif warga Muhammadiyah banyak dilakukan melalui pendidikan dalam Muhammadiyah itu sendiri. Pendidikan Muhammadiyah dapat memberikan tawaran pendidikan yang berbasis pada nilai-nilai agama sebagaimana disebutkan dalam keyakinan dan cita-cita Muhammadiyah. Dalam mewujudkan nilai-nilai tersebut, pendidikan Muhammadiyah tidak hanya didukung dengan mata pelajaran yang masuk kedalam mata pelajaran intrakurikuler saja, akan tetapi terdapat pula dalam mata pelajaran pendukung atau ekstrakurikuler, salah satunya adalah dalam tapak suci putera Muhammadiyah.

Tapak suci putera Muhammadiyah merupakan bagian terpenting dalam persyarikatan Muhammadiyah. Tapak suci putera Muhammadiyah dapat memberikan andil yang cukup besar dalam gerakan langkah kemajuan persyarikatan. Tapak suci putera Muhammadiyah biasanya menjadi bagian dari sekolah-sekolah dan menjadi bagian dari ekstrakurikuler dalam pendidikan karakter juga mendapat tempat yang cukup diperhitungkan adanya kegiatan-kegiatan ekstrakurikuler juga dapat menjadi wadah dalam pembentukan karakter pada siswa, termasuk dalam tapak suci putera Muhammadiyah.

Sekolah SMA Negeri 1 Malangke adalah Salah satu sekolah setingkat sekolah menengah atas yang organisasi beladiri tapak suci putera Muhammadiyah masuk dalam kegiatan ekstrakurikuler di SMA Negeri 1 Malangke sejak tahun 2006, yang dibentuk oleh Ibrahim Nasir selaku pelatih sekaligus kepala sekolah SMA Negeri 1 Malangke. Dari kegiatan ekstrakurikule tapak suci putera Muhammadiyah memberikan warna baru dalam pembentukan sikat atau mental peserta didik, terlihat setelah siswa masuk dalam kegiatan ekstrakurikuler tapak suci. Pembentukan sikap ini dapat dilihat dari perbedaan 
perilaku siswa yang mengikuti kegiatan ekstrakurikuler tapak suci dengan siswa yang tidak mengikuti kegiatan ekstrakurikuler tapak suci. Siswa yang mengikuti kegiatan ekstrakurikuler tapak suci cenderung lebih taat terhadap peraturan yang ada di sekolah seperti lebih disiplin, mengikuti sholat berjamaah, tepat waktu, serta lebih dapat bersikap sportif dan menghargai orang lain. Adanya kegiatan ekstrakurikuler tapak suci di SMA Negeri 1 Malangke, sebagai salah satu cara dalam menanamkan kependidikan karakter terhadap siswa. Penanaman karakter melalui kegiatan ekstrakurikuler tapak suci menjadi media yang efekti karena dapat mengembangkan bakat dan potensi dalam diri siswa. Sekolah SMA Negeri 1 Malangke berada diwilayah Kecamatan Malangke Kabupaten Luwu Utara. Di sekolah ini memiliki peserta didik di mana orang tua merupakan keluarga dari golongan menengah kebawah seperti keluarga petani, buruh, dan pekerja serabutan.

\section{LANDASAN TEORI}

Kegiatan ekstrakurikuler kepada siswa di harapkan mampu memberikan pengalaman hidup yang mereka butuhkan, melalui kegiatan ekstrakurikuler memberikan sumbangan yang berarti bagi siswa untuk mengembangkan minat-minat baru, menanamkan tanggung jawab sebagai warga negara, melalui pengalaman pembentukan karakter kerja sama, kemandirian, disiplin, toleran dan membangun karakter-karakter positif lainnya, jangan biarkan mereka mencari sendiri ruang ekspresi diri tanpa pengarahan dari guru, orang tua dan lingkungan sekitar. Usia pelajar adalah usia yang penuh energi, meraka dalam tahap pencarian jati diri, mereka butuh wadah untuk mengekspresikan diri, pengakuan dari kelompok, butuh perhatian, mereka penuh petualangan. Pelajar butuh ruang ekspresi diri, jika tidak diwadahi mereka akan melampiaskannya dengan tanpa pengawalan, tanpa pendampingan dan bisa berakibat mereka negatif ke diri mereka sendiri, bahkan merugikan orang lain, oleh karena itu perlu diberikan kegiatan ekstrakurikuler bagi para pelajar.

Kegiatan ekstrakurikuler di sekolah merupakan kegiatan tambahan di luar jam formal dikelas, jika dinilai kegiatan belajar di kelas dirasa masih kurang, maka perlu adanya kegiatan tambahan yaitu kegiatan ekstrakurikuler yang orientasinya bukan hanya kepada pengembangan bakat mereka, tetapi kepada pembinaan karakter mereka. Ekstrakurikuler diharapkan mampu melatih respon positif, dan sekaligus respon spontan peserta didik dalam memecahkan problem yang mereka hadapi, dengan kata lain mereka mempunya akhlaq (budi pekerti) yang baik, sehigga diharapakan mereka tidak lagi mudah marah, gampang tersinggung, intoleran, egois dan lain sebagainya. 
Ekstrakurikuler diharapkan menjadi alternatif untuk mengurangi tindak atau perilaku negatif pelajar, misalnya: tawuran, geng motor pelajar, perilaku seks bebas, narkoba dan lain sebagainya. Adapun manfaat kegiatan ekstrakurikuler antara lain : 1) Wadah untuk mengembangkan potensi, bakat dan minat yang sudah di miliki siswa. 2) Upaya memupuk dan mengembangkan tanggung jawab pribadi dan social siswa. 3) Dapat menciptakan suasana rileks, gembira dan menyenangkan. 4.Dapat memberikan bekal untuk mempersiapkan karir siswa.

Bentuk kegiatan ekstrakurikuler yang dilakukan di sekolah juga mempertimbangkan kondisi dan sarana prasana yang ada. Karena Sarana dan prasarana sangat penting dalam dunia pendidikan karena sebagai alat penggerak suatu pendidikan. Sarana dan prasarana pendidikan dapat berguna untuk menunjang penyelenggaraan proses belajar mengajar, baik secara langsung maupun tidak langsung dalam suatu lembaga dalam rangka mencapai tujuan pendidikan. Prasarana dan sarana pendidikan adalah salah satu sumber daya yang menjadi tolok ukur mutu sekolah dan perlu peningkatan terus menerus seiring dengan perkembangan ilmu pengetahuan dan teknologi yang cukup canggih. Dari konsep yang telah tertera di atas maka penelitian ini menggunakan teori interaksionisme simbolik yang dikemukakan oleh Herbert Mead, dasar dari interaksionisme simbolik sebenarnya tak mudah menggolongkan pemikiran ini kedalam teori dalam artian umum karena seperti dikatakan Paul Rock, pemikiran ini sengaja di bangun secara samar dan merupakan resistensi terhadap sistematisasi. Ada beberapa perbedaan signifikan dalam interaksionisme simbolik. Pembelajaran mengenai makna dan simbol Mead mengatakan, teoritisi interaksionisme simbolik cenderung menyetujui pentingnya sebab musabab interaksi sosial. Dengan demikian, makna bukan berasal dari proses mental yang menyendiri, tetapi berasal dari interaksi. Tindakan dan interaksi manusia, bukan pada proses mental yang terisolasi, bukan bagaimana cara mental manusia menciptakan arti dan simbol, tetapi bagaimana cara mereka mempelajarinya selama interaksi pada umumnya dan selama proses sosialisasi pada khususnya.

Simbol adalah objek sosial yang dipakai untuk mempresentasikan (atau menggantikan) apa pun yang di setujui orang yang akan mereka representasikan. Teoritisi interaksionisme simbolik membayangkan bahasa sebagai sisitem simbol yang sangat luas. Disamping itu simbol pada umumnya, dan bahasa pada khususnya, mempunyai sejumlah fungsi khusus yaitu: 1.Simbol memungkinkan orang menghadapi dunia material dan dunia sosial dengan memungkinkan mereka untuk mengatakan, menggolongkan dan 
mengingat objek yang mereka jumpai di situ. 2.Simbol meningkatkan kemampuan manusia untuk memahami lingkungan. 3.Simbol meningkatkan kemampuan untuk berfikir. 4.Simbol meningkatkan kemampuan untuk menyelesaikan berbagai masalah. 5.Simbol juga memungkinkan aktor mendahului waktu, ruang, dan bahkan pribadi mereka sendiri.

Menurut Max weber bahwa Manusia sebagai makhluk individu sekaligus sebagai makhluk sosial senantiasa melakukan hubungan dengan manusia lain menurut kesanggupannya masing-masinng. Hubungan sosial yang bersifat timbal balik biasanya dikenal dengan istilah interaksi sosial. Syarat terjadinya interaksi sosial adalah adanya kontak dan komunikasi sedangkan inti dari kontak sosial adalah tindakan sosial. Tindakan sosial adalah suatu tindakan yang memiliki makna yaitu ketika individu yang berinteraksi dengan individu lain dan hasilnya individu tersebut dapat mempengaruhi perilaku individu lainnya. Karena pada realitanya menurut Weber pemikiran manusia atau individu masing-masing memiliki bentuk dan metode yang berbeda-beda, sehingga memunculkan tindakan-tindakan yang berbeda dan saling mempengaruhi. Max Weber mengklasifikasikan ada empat jenis tindakan social sebagai berikut: a.Tindakan rasional bersifat instrumental, adalah tindakan yang di tujukan pada pencapaian tujuan-tujuan yang secara rasional di perhitungkan dan di upayakan sendiri oleh individu yang bersangkutan. b. Tindakan yang rasional berdasarkan nilai (value-rational action) yang di lakukan untuk alasan-alasan dan tujuan-tujuan yang ada kaitannya dengan nilai-nilai yang di yakini secara personal tanpa memperhitungkan prospek-prospek yang ada kaitannya dengan berhasil atau gagalnya tindakan tersebut. c. tindakan afektif, yang di tentukan oleh kondisi-kondisi dan orientasi-orientasi emosional si individu. d. Tindakan tradisional yang di tentukan oleh kebiasaan-kebiasaan yang sudah mengakar secara turum menurun.dan tindakan tradisional yang ditentukan oleh kebiasaan-kebiasaan yang sudah mengakar secara turum menurun. Max Weber mengakui bahwa empat jenis tindakan social yang di utarakan adalah merupakan tipe ideal dan jarang bias ditemukan dalam kenyataan. Tetapi, lepas dari soal itu, apa yang hendak di sampaikan Weber adalah bahwa tindakan social, apa pun wujudnya hanya dapat di mengerti menurut arti subjektif dan pola-pola motivasional yang berkaitan dengan itu. Untuk mengetahui arti subjektif dan motivasi individu yang bertindak, yang di perlukan adalah kemampuan untuk berempati pada peranan orang lain. 


\section{METODE PENELITIAN}

Pendekatan yang digunakan dalam penelitian ini adalah pendekatan kualitatif dimana suatu pendekatan yang mengungkap situasi sosial tertentu dengan mendeskripsikan kenyataan secara benar, di bentuk oleh kata-kata berdasarkan teknik pengumpulan dan analisis data yang relevan yang di peroleh dari situasi yang alamiah. Penelitian kualitatif tidak hanya sebagai upaya mendeskripsikan data tetapi desekripsi tersebut hasil dari pengumpulan data yang sohid yang di persyaratkan kualitatif yaitu wawancara mendalam, observasi partisipasi, studi dokumen, dan dengan melakukan triangulasi. Menyatakan bahwa penelitian kualitatif adalah penelitian yang menggunakan latar alamiah, dengan maksud menafsirkan fenomena yang terjadi dan di lakukan dengan jalan melibatkan berbagai metode yang ada. yaitu penelitian yang menggambarkan atau melukiskan situasi tertentu berdasarkan data yang di peroleh secara terperinci sesuai permasalahan yang di tetapkan dalam penelitian ini. Informan ditentukan secara purposive sampling, teknik pengumpulan data yaitu observasi, wawancara, dan dokumentasi, kemudian dianalisis melalui tahapan pengumpulan data, dan Teknik keabsahan data triangulasi sumber, waktu, dan teknik.

\section{PEMBAHASAN}

Dalam hal ini kegiatan ekstrakurikuler tapak suci di SMA Negeri 1 Malangke ini sebagai wadah atau tempat untuk membentuk karekter siswa dan mengembangkan bakat serta keterampilan, bela diri, seni, olahraga dan spritual dan dalam kegiatan ini pula terdapat cara yang digunakan dalam pendidikan kerohanian selalu diberikan sebagai mata pelajaran Utama dan prosesnya dengan diikuti, dibimbing dan diawasi secara langsung oleh sang pelatih, sehingga siswa yang berguru diketahui dengan jelas perkembangan kemampuannya, terutama pada pembentukkan karakternya dan kemampuan pengendalian diri atau budi pakertinya.

Salah satu kegiatan ekstrakurikuler tapak suci yang ada di SMA Negeri 1 Malangke dalam membentuk karakter siswa yaitu dengan pendidikan karekter berbasis potensi diri. Pendidikan karakter berbasis potensi diri yang diarahkan untuk mengembangkan segala potensi yang dimiliki oleh siswa tapak suci dan meningkatkan kualitas pendidikan.

Pendidikan karakter berbasis potensi diri yang terdapat dalam ekstrakurikuler tapak suci di SMA Negeri 1 Malangke dapat membentuk karakter siswa apabila dilaksanakan dengan maksimal, antara lain: 1. Proses kegiatan karakter berbasis potensi 
diri, pelatih tidak hanya berperan sebagai pengajar yang menyampaikan materi pengajaran, tetapi juga bertindak sebagai inspirator, inisiator, fasiliator, mediator, supervisor, evaluator, teman sekaligus pembimbing, lebih matang, otoritas akademik dan sepenuh hati dengan cinta hati dan kasih sayang. 2. Siswa mampu mengatasi dirinya, sehingga anak menjadi mandiri dan mampu mengatasi segala masalah yang dihadapinya. 3. Seseorang bebas menyatakan pendapat yang dimilikinya tanpa ada tekanan dari pihak mana pun. 4. Dapat melakukan penalaran, penalaran merupakan kemampuan berpikir logis dan analitis sehingga teruji kebenarannya. 4. Segala potensi yang ada pada diri anak bersifat unik, dalam proses pendidikan karakter semua potensi yang dimiliki anak digali dan diberdayakan untuk bekal hidup mereka. Jika kegiatan ekstrakurikuler tapak suci ini dilaksanakan secara profesional, maka akan menjadi media efektif dalam mengembangkan bakat dan potensi dalam diri siswa, serta membentuk karakter pemenang pada diri anak.

Kegiatan ekstrakurikuler tapk suci di SMA Negeri 1 Malangke dapat diselenggarakan melalui kegiatan olah raga dan seni dalam membentuk pembelajaran, pelatihan, kompetisi atau festival. Berbagai kegiatan olah raga dan seni tersebut diorientasikan terutama untuk penanaman dan pembentukkan sikap, perilaku dan pribadian para pelaku olah raga atau seni agar menjadi manusia indonesia berkarakter.

Berdasarkan uraian di atas, maka dapat ditetapkan beberapa teori yang berkaian, sebagai berikut : 1 . Teori interaksionisme simbolik mempembelajaran mengenai makna dan simbol Mead mengatakan, teoritisi interaksionisme simbolik cenderung menyetujui pentingnya sebab musabab interaksi sosial. Dengan demikian, makna bukan berasal dari proses mental yang menyendiri, tetapi berasal dari interaksi. Tindakan dan interaksi manusia, bukan pada proses mental yang terisolasi, bukan bagaimana cara mental manusia menciptakan arti dan simbol, tetapi bagaimana cara mereka mempelajarinya selama interaksi pada umumnya dan selama proses sosialisasi pada khususnya. Simbol adalah objek sosial yang dipakai untuk mempresentasikan (atau menggantikan) apa pun yang di setujui orang yang akan mereka representasikan. Teoritisi interaksionisme simbolik membayangkan bahasa sebagai sisitem simbol yang sangat luas. Teori tindakan social menyatakan bahwa Manusia sebagai makhluk individu sekaligus sebagai makhluk sosial senantiasa melakukan hubungan dengan manusia lain menurut kesanggupannya masing-masinng. Hubungan sosial yang bersifat timbal balik biasanya dikenal dengan istilah interaksi sosial. Syarat terjadinya interaksi sosial adalah adanya kontak dan komunikasi sedangkan inti dari kontak sosial adalah tindakan sosial. Tindakan sosial 
adalah suatu tindakan yang memiliki makna yaitu ketika individu yang berinteraksi dengan individu lain dan hasilnya individu tersebut dapat mempengaruhi perilaku individu lainnya. Karena pada realitanya menurut Weber pemikiran manusia atau individu masing-masing memiliki bentuk dan metode yang berbeda-beda, sehingga memunculkan tindakan-tindakan yang berbeda dan saling mempengaruhi.

Max Weber mengklasifikasikan ada empat jenis tindakan social sebagai berikut: 1. Tindakan rasional bersifat instrumental. 2. Tindakan yang rasional berdasarkan nilai. 3 . Tindakan afektif, yang di tentukan oleh kondisi-kondisi dan orientasi-orientasi emosional si individu. 4. Tindakan tradisional yang di tentukan oleh kebiasaan-kebiasaan yang sudah mengakar secara turum menurun

\section{KESIMPULAN}

Nilai-nilai karakter yang terdapat dalam kegiatan ekstrakurikuler tapak suci di SMA Negeri 1 malangke antara lain nilai kedisiplinan, religius, cinta tanah air, kreatif, komunikatif, menghargai prestasi, dan peduli sosial. Nilai-nilai karakter tersebut dapat terlihat dari sikap siswa baik selama kegiatan latihan berlangsung, maupun di luar kegiatan latihan. Proses pembentukkan nilai-nilai karakter dalam kegiatan ekstrakurikuler tapak suci di SMA Negeri 1 Malangke dilaksanakan berbagai pelaksanaan seperti nilai disiplin, melalui datang tepat waktu, menaati peraturan, dan disiplin beribadah. Nilai religius ditanamkan melalui berdoa sebelum dan sesudah latihan, wisata alam, melaksanakan shalat. Nilai kreatif ditanamkan melalui penguasaan gerakkan jurus tapak suci dan melalui kegiatan seperti bakti sosial yang memancing daya fikir siswa. Nilai komunikatif ditanamkan melalui kegiatan dan penugasan kelompok serta siswa yang dekat dengan pelatih untuk bercerita masalahnya. Nilai menghargai prestasi ditanamkan melalui pemberiaan penghargaan bagi siswa yang menang pertandingan dan menerima kekalahan jika belum berhasil menang. Nilai cinta tanah air ditanamkan menggunaan seragam tapak suci dan bahasa resmi ketika latihan serta melalui pengajaran materi ketapak suci-an. Nilai peduli sosial ditanamkan melalui kegiatan yang berguna bagi kepentingan bersama seperti bakti sosial. Faktor yang menjadi penghambat pelaksanaan ekstrakurikuler tapak suci di SMA Negeri 1 Malangke kabupaten Luwu Utara diantaranya dari pihak keterbatasan waktu, tempat latihan yang kurang luas, keterbatasan dana, orang tua yang menanjakan anak, kurangnya sarana dan prasarana dan pengajaran materi yang tidak seimbang. 


\section{DAFTAR PUSTAKA}

Afifuddin. (2012). Metodologi Penelitian Kualitatif. Bandung : CV . Pustaka Setia.

Budiningsih, Asri. (2005). Belajar dan Pembelajaran. Jakarta: Rineka Cipta.

Fakultas Keguruan Dan Ilmu Pendidikan. (2015). Pedoman Penulisan Skripsi.Makassar.Unismuh Makassar.

Hasbullah. (2005). Dasar-Dasar Ilmu Pendidikan. Jakarta: Edisi Revisi.

Kasman, Yusniar. (2014). Peran Orang Tua Terhadap Penanaman Nilai-Nilai Sosial Pada Perilaku Remaja Di Desa Baraka Kabupaten Enrekang. Makassar: Universitas Muhammadiyah Makassar.

Komariah, Aan. (2014). Metodologi Penelitian Kualitatif. Bandung: Alfaabeta.

Muhammadiyah, Marham. (2012). Perkembangan Peserta Didik. Makassar : Universitas Muhammadiyah Makassar.

Narwoko, J. Dwi \& Suyanto, Bagong. (2010). Sosiologi Teks Pengantar Dan Terapan. Jakarta: Kencana Predada Media Group.

Poloma, Margaret M. (2010). Sosiologi Kontemporer.Jakarta. Raja Grafindo persada.

Ruliana, Poppy. (2014). Komunikasi Organisasi. Jakarta: PT.Raja Grafindo Persada.

Supriadi. (2014). Laporan Kemuhammadiyaan. Makassar: Fakultas Keguruan Dan Ilmu Pendidikan. Unismuh Makassar.

Suwaryo. (2008). Peranan Organisasi Perguruan Seni Belah Diri Pencak Silat Dalam Meminimalisasi Kejahatan, Skipsi. Program Magister Ilmu hukum UD Semarang.

Syamsuddin. (2011). Praktis Realitas Sosial Dulu Dan Sekarang (Pendekatan Sosiologi Klasik Dan Modern). Makassar:Unismuh Makassar.

Tukijan, Eddy. (2009). Sosiologi Pendidikan. Makassar: Adika.

Zuhrotunnisa, Ulfa. (2013). Internalisasi Nilai-Nilai Pendidikan Karakter Dalam Ektrakurikuler Tapak Suci Putera Muhammadiyaan, skripsi. Fakultas Ilmu Tarbiyah dan Keguruan UIN Sunan Kalijaga Yogyakarta. 